\title{
Attempts to Transfer Elaphostrongylus alces from Moose (Alces alces) to Sheep and Goats
}

\author{
By Gudbrand Stuve and Arne Skorping \\ National Veterinary Institute, Oslo, Department of Large Animal Clinical Sciences, \\ Parasitology Section, Norwegian College of Veterinary Medicine, Oslo and \\ Institute of Biology and Geology, University of Tromsø, Norway.
}

\begin{abstract}
Stuve, G. and A. Skorping: Attempts to transfer Elaphostrongylus alces from moose (Alces alces) to sheep and goats. Acta vet. scand. 1990, 31, 409-412. - Six 1 year old female and 6 four months old male goats were inoculated different numbers of $E$. alces third-stage larvae. Protostrongylid larvae were not detected in the faeces of these animals during the experiment. At the end of the experimental period the animals were euthanized and autopsied. Neither parasites nor pathological lesions related to larval or adult stages of $E$. alces could be demonstrated.
\end{abstract}

cervidae; protostrongylidae; small ruminants.

\section{Introduction}

A protostrongylid nematode in the genus Elaphostrongylus occurs endemically in moose in Scandinavia (Steen \& Rehbinder 1986, Stuve 1986). It has recently been proposed as a separate species, named $E$. alces (Steen et al. 1989, Gibbons et al. in manuscript).

In Norway livestock often graze in areas where moose are present. The high prevalence of E. alces infection in moose (Stuve 1986, Stuve 1987) and reports on elaphostrongylosis due to E. rangiferi (Mitskevitch 1958 ) in goats (Helle pers. comm., Sparboe \& Handeland pers. comm.) and in sheep and calves (Bakken et al. 1975) caused attention to be drawn to the question of possible $E$. alces infection in domestic ruminants.

This paper presents the results of an attempt to transfer E. alces isolated from moose to sheep and goats.

\section{Materials and methods}

Rearing of infective third-stage larvae

First-stage larvae (L1) of E. alces were iso- lated by baermannisation of faeces from an experimentally infected moose calf (Stuve \& Skorping 1987). Laboratory-reared snails of Arianta arbustorum were exposed to approximately $10,000 \mathrm{Ll}$ per 20 snails for 2 h. After incubation for 2 months at $20^{\circ} \mathrm{C}$ the soft tissue of the snails was examined in a trichinoscope compressor. L3 of E. alces were identified and counted.

\section{Experimental design}

A total of 6 one year old female sheep and 6 four months old male goats were infected with third-stage larvae (L3) of E. alces. Two sheep and 2 goats were each given $900 \mathrm{L3}, 2$ sheep and 2 goats received 400 , and the last 2 sheep and 2 goats were given $100 \mathrm{~L} 3$. The animals were kept indoors to prevent exposure to natural infections with elaphostrongylid nematodes.

The general condition and behaviour of the animals were recorded daily throughout the experiment. Faecal samples were examined weekly for protostrongylid first-stage larvae after baermannisation and for nematode eggs 
after flotation in saturated $\mathrm{NaCl}$-solution. Haematological examinations were carried out weekly for packed cell volume (PCV), haemoglobin $(\mathrm{Hb})$, and differential white blood cell counts.

One sheep inoculated with 900 L3 and another sheep inoculated with 400 L3 were autopsied 10 and 11 weeks after inoculation. One sheep inoculated with $100 \mathrm{~L} 3$ and 3 goats inoculated with 900,400 and $100 \mathrm{~L} 3$, respectively, were euthanized, bled and autopsied 18 weeks after inoculation. The last 3 sheep and 3 goats were euthanized, bled and autopsied 23 weeks after inoculation.

The central nervous system, lungs, fasciae, skeletal muscles, peripheral nerves, and lymph nodes of all experimental animals were examined for occurrence of nematodes, protostrongylid larvae, and gross pathological lesions. Specimens from the central nervous system, lungs, peripheral nerves, skeletal muscles, heart, liver, kidney, and spleen were fixed in $10 \%$ neutral buffered formalin, processed routinely, and embedded in paraffin. Sections at 5-6 $\mu \mathrm{m}$ were stained with haematoxylin and eosin and examined microscopically.

\section{Experimental animals}

All 6 sheep used in the experiment had been on pasture the previous summer. At the time of inoculation with L3 of E. alces they were all shedding a small number of gastrointestinal strongylid eggs (20-440 EPG). However, it was considered that these animals had not previously been exposed to Elaphostrongylus spp. as no cervids occur in the area where they had been grazing. The 6 goats used had been kept indoors prior to the experiment and had not been exposed to any parasitic nematodes.

\section{Results}

Protostrongylid larvae could not be demonstrated from any of the inoculated sheep and goats during the experiment. No changes were recorded in the general condition, behaviour, or haematology with exception of 2 sheep suffering lethal haemonchosis.

Neither parasites nor pathological changes related to larval or adult stages of $E$. alces could be demonstrated in any of the experimental animals.

Four weeks after inoculation, 2 of the sheep inoculated with 900 and $400 \mathrm{L3}$, respectively, showed a marked increase in excretion of strongylid eggs. Nine weeks post inoculation the output reached a peak of 47,000 and 43,300 EPG, respectively. At the same time the PCV dropped from 25 and $32 \%$ to 6 and $10 \%$, and the $\mathrm{Hb}$ dropped from 8.0 and $10.6 \mathrm{~g} / 100 \mathrm{ml}$ to 1.3 and $2.6 \mathrm{~g} / 100 \mathrm{ml}$. The 2 sheep died 10 and 11 weeks post inoculation due to heavy infection with Haemonchus contortus.

The 4 remaining sheep continued shedding a small number of strongylid eggs and showed normal haematological values throughout the experiment.

\section{Discussion}

The prepatent period for elaphostrongylid infections in different cervids has been reported to be 2-4 months (Mitskevich 1964, Lankester 1977, Stuve \& Skorping 1987). The period from inoculation to euthanasia of the animals in this experiment ought therefore to have been sufficient for establishment of an infection.

To prove the infectivity of the $\mathrm{L} 3$ used in the experiment a control inoculation on moose should have been undertaken. However, this was not possible due to inaccessibility of moose for experimental use. Furthermore, the method used for rearing infec- 
tive larvae is well established and has proven effective (Stuve \& Skorping 1987).

The occurrence of gastrointestinal nematodes in the sheep might have interfered with the possibilities of establishing experimental infections with E.alces. However, this is considered as unlikely.

The experiment started in mid March and the 2 sheep which died seem both to have harboured large numbers of hypobiotic $H$. contortus larvae. These larvae developed to maturity during the experiment and caused lethal haemonchosis. It was decided not to treat any of the experimental animals with anthelmintics in order to avoid interference with the experiment. However, the period of time between inoculation and death of the 2 sheep suffering lethal haemonchosis is considered sufficiently long for allowing development of pathological changes due to migrating larvae or adult $E$. alces.

The results presented in this paper indicate that $E$.alces from moose can not establish itself in small domestic ruminants. E. rangiferi from reindeer on the other hand seems to cause pathological lesions in goats (Sparboe \& Handeland pers. comm.), sheep and cattle (Bakken et al. 1975).

Differences between elaphostrongylid parasites in the ability to establish infection in livestock seems to confirm that reindeer and moose each have their own host specific species of Elaphostrongylus (Steen et al. 1989, Gibbons et al. in manuscript).

\section{Conclusion}

The absence of larval and adult stages of $E$. alces and pathological changes related to them indicate that sheep and goats can not become infected with this parasite. Furthermore, there seems to be no risk involved in grazing small domestic ruminants in areas where E. alces occurs endemically in the moose population.

\section{Acknowledgements}

This study was financially supported by the Norwegian Agricultural Research Council. We thank Professor O. Helle and Dr. G. Holt for fruitful criticism.

\section{References}

Bakken $G$, Helle $O$, Sparboe $O$, Solhøy $T$ : Experimental Elaphostrongylus rangiferi infection in calves and lambs. Nord. Vet. Med. 1975, 27, 220-223.

Gibbons L, Halvorsen $O$, Stuve $G$ : Review of the genus Elaphostrongylus Cameron, 1931 (Nematoda, Metastrongyloidea) with particular reference to the genus occurring in Norwegian cervids. In manuscript.

Lankester $M V$ : Neurological disorders in moose caused by Elaphostrongylus cervi Cameron 1931, from caribou. Proc. 13th North American Moose Conference and Workshop. Jasper, Alberta 1977, 177-190.

Mitskevich WJ: The development cycle of Elaphostrongylus rangiferi sp. 1958. Sbornik, "Parazity sel skokhoziastv. Zhivotnykh Kazakhstana" 1964, 3, 49-60. (In Russian).

Steen $M$, Rehbinder $C$ : Nervous tissue lesions caused by Elaphostrongylosis in Swedish wild moose. Acta vet. scand. 1986, 27, 326-342.

Steen $M$, Chabaud A, Rehbinder $C$ : Species of the genus Elaphostrongylus parasite of Swedish Cervidae. A description of E. alces n. sp. Ann. Parasitol. Hum. Comp. 1989, 64, 134-142.

Stuve $G$ : The prevalence of Elaphostrongylus cervi infection in moose (Alces alces) in Southern Norway. Acta vet. scand. 1986, 27, 397409.

Stuve G: Elaphostrongylus cervi infection in moose (Alces alces). Prevalence and pathological changes in relation to age and season. Acta vet. scand. 1987, 28, 157-164.

Stuve G, Skorping A: Experimental Elaphostrongylus cervi infection in moose (Alces alces). Acta vet. scand. 1987, 28, 165-171. 


\author{
Sammendrag \\ Forsok på å overfore Elaphostrongylus alces \\ fra elg (Alces alces) til sau og geit. \\ Seks årsgamle søyer og 6 fire måneder gamle geite- \\ bukker ble forsøkt infisert med ulike doser av \\ tredjestadiums Elaphostrongylus alces larver. Pro-
}

tostrongylid-larver ble ikke påvist $\mathrm{i}$ avføringen hos forsøksdyrene på noe tidspunkt $\mathrm{i}$ forsøket. Forsøksdyrene ble avlivet og obdusert henholdsvis 18 og 23 uker etter inokuleringen. Hverken parasitter eller patologiske forandringer relatert til $E$. alces ble påvist hos forsøksdyrene.

(Received July 23, 1989; accepted December 13, 1989).

Reprints may be requested from: G. Stuve, National Veterinary Institute, P. O. Box 8156 Dep., N-0033 Oslo 1, Norway. 